\title{
First record of leucism for Atractus reticulatus (Serpentes: Dipsadidae)
}

\author{
O. M. Entiauspe-Neto ${ }^{a}$, A. D. Abegg ${ }^{b *}$, F. M. Quintela ${ }^{a}$, C. Mario-da-Rosa ${ }^{c}$, \\ L. Malta-Borges ${ }^{d}$ and D. Loebmann ${ }^{a}$ \\ ${ }^{a}$ Laboratório de Vertebrados, Instituto de Ciências Biológicas, Universidade Federal do Rio Grande - FURG, \\ Av. Itália, Km 8, Vila Carreiros, CEP 96203-900, Rio Grande, RS, Brazil \\ ${ }^{\text {b} L a b o r a t o ́ r i o ~ E s p e c i a l ~ d e ~ C o l e c ̧ o ̃ e s ~ Z o o l o ́ g i c a s, ~ I n s t i t u t o ~ B u t a n t a n, ~ A v . ~ V i t a l ~ B r a s i l, ~ 1500, ~ C E P ~ 05503-900, ~}$ \\ São Paulo, SP, Brazil \\ 'Laboratório de Herpetologia, Universidade Federal de Santa Maria - UFSM, Av. Roraima, 1000, \\ CEP 97105-000, Santa Maria, RS, Brazil
}

dLaboratório de Sistemática, Entomologia e Biogeografia, Universidade Federal de Santa Maria - UFSM, Av. Roraima, 1000, CEP 97105-000, Santa Maria, RS, Brazil

*e-mail: arthur_abegg@hotmail.com

Received: June 15, 2016 - Accepted: September 1, 2016 - Distributed: February 28, 2018

(With 1 figure)

\section{Introduction}

Wild albino and leucistic animals are usually rare, partially due to to their low survival rates, considering that specimens within these conditions may hatch stillborn, with malformations, and are easier to be detected by prey and predators than their normally colored counterparts, with negative impacts on their feeding and reproductive capabilities (Walter, 1938; Oliveira, 2009; Krecsák, 2008; Noronha et al., 2013)

In this work, we follow the proposal of Van Grouw (2006), who considers leucism as a partial or total lack of eumelanin and phaeomelanin due to an inherited disorder in pigment transfer, which causes fail in melanin deposition within cells, although maintaining pigments in the back of the eyeball but not in the iris.

Here, we report the first record of leucism for Atractus reticulatus, a fossorial species of ground snake inhabiting the Pampas, Campos, southern Cerrado and transitional zones, occurring from Lowland to Lower Montane Semi-deciduous Forests between 0-1100 m high, from
Southeastern and Southern Brazil, to Argentina and Uruguay (Passos et al., 2010).

On May 12, 2016, the authors accidentally came across an adult female specimen of $A$. reticulatus with leucism, under construction debris in the Universidade Federal de Santa Maria campus, urban zone of Santa Maria (2942'26.2” S, 5351'52.3”W), Rio Grande do Sul, Brazil. The specimen was photographed, collected under permit (ICMBio 43658) and deposited in the herpetological collection of the Universidade Federal do Rio Grande (Rio Grande, Brazil) under the voucher CHFURG 4841.

The specimen characteristics (snout-vent length $=295 \mathrm{~mm}$; tail length $=42 \mathrm{~mm}$; mass $=14.94 \mathrm{~g}$; ventral scales $=151$; subcaudal scales $=33$ ) matches the diagnosis of Passos et al. (2010). The specimen presents a uniform dorsal and ventral white coloration with few dorsal scales margined by vestigial orange or black pigmentation, and uniform black eye with red iris (Figure 1).

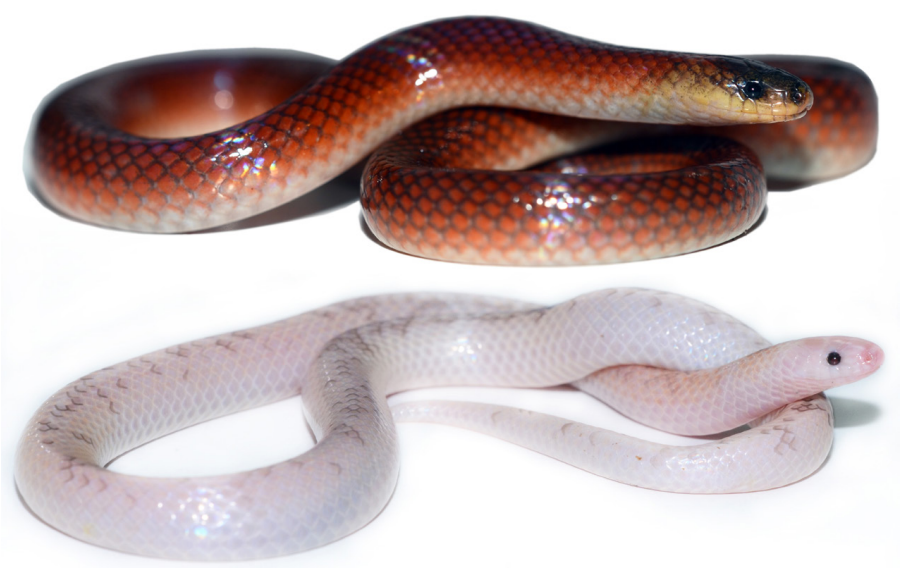

Figure 1. Normal (Top, Unvouchered) and leucistic (Bottom, CHFURG 4841) specimens of Atractus reticulatus. 
This is the first record of leucism in the wild for genus Atractus. Our finding seems to corroborate recent studies suggesting that chromatic anomalies might be more common in species of crepuscular, nocturnal, cryptozoic or fossorial habits, with reduced impact for predation by visually-oriented predators (e.g. Sazima and Di-Bernardo, 1991; Esqueda et al., 2005; Abegg et al., 2014, 2015). Leucism seems to be a very rare condition in A. reticulatus, considering that even being an abundant species in inland portions of Rio Grande do Sul state, and yet, no other similar specimens were reported or encountered in herpetological collections.

\section{Acknowledgements}

We thank Ray Morgan for kindly providing an English revision of the manuscript.

\section{References}

ABEGG, A.D., ENTIAUSPE-NETO, O.M. and LEMA, T., 2015. First record of albinism in the Elapomorphini tribe (Serpentes: Dipsadidae). Herpetology Notes, vol. 8, pp. 503-505.

ABEGG, A.D., MARIO-DA-ROSA, C., CAVALHEIRO, C.P., ORTIZ, F.R. and MALTA-BORGES, L., 2014. Partial albinism in Sibynomorphus ventrimaculatus (Boulenger, 1885) (Serpentes: Dipsadidae) in Rio Grande do Sul state, Brazil. Herpetology Notes, vol. 7, pp. 475-476.
ESQUEDA, L.F., LA MARCA, E. and SORIANO, P., 2005. Partial albinism in a Venezuelan specimen of false coral snake, Oxyrhopus petola petola (Linnaeus, 1758). Herpetotropicos: Tropical Amphibians \& Reptiles, vol. 2, no. 2, pp. 114-115.

KRECSÁK, L., 2008. Albinism and leucism among European Viperinae: a review. Russian Journal of Herpetology, vol. 15, no. 2, pp. 97-102.

NORONHA, J.C., BARROS, A.B., MIRANDA, R.M., ALMEIDA, E.J. and RODRIGUES, D.J., 2013. Record of leucism in Pseudoboa nigra (Serpentes: Dipsadidae) in southern Amazon, Brazil. Herpetology Notes, vol. 6, pp. 81-82.

OLIVEIRA, S.V., 2009. Albinismo parcial em Cutia Dasyprocta azarae (Lichtenstein, 1823) (Rodentia, Dasyproctidae), no sul do Brasil. Biotemas, vol. 22, pp. 243-246.

PASSOS, P., FERNANDES, R., BERNILS, R.S. and MOURALEITE, J.D., 2010. Taxonomic revision of the Brazilian Atlantic Forest Atractus (Reptilia: Serpentes: Dipsadidae). Zootaxa, no. 2364, pp. 1-63.

SAZIMA, I. and DI-BERNARDO, M., 1991. Albinismo em serpentes neotropicais. Memorias do Instituto Butantan, vol. 53, no. 2, pp. 167-173.

VAN GROUW, H., 2006. Not every white bird is an albino: sense and nonsense about colour aberrations in birds. Dutch Birding, vol. 28 , no. 2 , pp. 79-89.

WALTER, H.E., 1938. Genetics: an introduction to the study of heredity. New York: Mac-Millan, pp. 422. 